\title{
FIELD EXPERIMENT ON BEACH NOURISHMENT USING GRAVEL AT JINKOJI COAST
}

\author{
Takayuki Kumada ${ }^{1}$, Takaaki Uda ${ }^{1}$, Takeo Matsu-ura ${ }^{2}$ and Michio Sumiya ${ }^{1}$ \\ Beach nourishment using $87,000 \mathrm{~m}^{3}$ of gravel with grain size between 2.5 and $13 \mathrm{~mm}$ was experimentally carried out \\ until April 2008 at the Jinkoji coast, which faces the Pacific Ocean and is surrounded by artificial headlands. \\ Monitoring surveys, a boring test and core sampling on the beach were carried out to investigate the mechanism of \\ the formation of gravel layers and their effect on protecting the foot of the seawall. It was found that the nourishment \\ gravel was deposited with a slope of $1 / 8$ at the foot of the seawall, thus providing some protection to the seawall, and \\ that the nourishment gravel was stably deposited without offshore discharge.
}

Keywords: beach nourishment; gravel; artificial headland; monitoring survey; change in grain size

\section{INTRODUCTION}

On the Kashimanada coast facing the Pacific Ocean, severe beach erosion has occurred since the 1980s due to the construction of the breakwater of Kashima Port. As a countermeasure, artificial headlands have been constructed to stabilize the sandy beach, and the construction of the majority of headlands has been completed (Matsu-ura et al., 2008). However, on the Jinkoji coast located between headland Nos. 6 and 7, beach erosion is still severe without any recovery of the foreshore in front of the seawall, and wave overtopping damage has frequently occurred. In the past, beach nourishment using dredged materials was conducted to recover the sandy beach, but all the nourishment sand was discharged offshore without any lasting effect of the nourishment, suggesting that the grain size selected for the nourishment sand was inadequate. To solve this problem, a field experiment on beach nourishment using gravel, the grain size of which ranged between 2.5 and $13 \mathrm{~mm}$, was planned and beach nourishment started in November 2005, taking the high stability of gravel beaches into account (Kumada et al., 2007; Komar, 2007). By April 2008, 87,000 $\mathrm{m}^{3}$ of gravel had been nourished between headland Nos. 6 and 7. During this project, monitoring surveys were carried out from the beginning to the completion of beach nourishment. We first investigated the datasets obtained to clarify the change in the sand volume of the beach and foreshore area. After the completion of the nourishment, further monitoring surveys, core sampling and a boring test were carried out in 2008 as well as wave observation. We next investigated the mechanism of the formation of gravel layers and their effect on protecting the foot of the seawall, particularly focusing on the stability and effectiveness of beach nourishment using gravel.

\section{BEACH NOURISHMENT USING GRAVEL}

\section{(1) Foreshore changes}

The experimental beach nourishment started on November 15, 2005 and ended in April 2008. During this period, $87,000 \mathrm{~m}^{3}$ of gravel was used for nourishment between headland Nos. 6 and 7 (Fig. 1). At first, gravel was supplied at a location immediately to the south of headland No. 7 , and then from the central area between headland Nos. 6 and 7 and to the north of headland No. 6 . The bathymetry on October 28, 2008, after the beaches had been subjected to exposure to waves, is shown in Fig. 1. The nourishment gravel was deposited along the shoreline and formed a foreshore. Before the nourishment, there were no sandy beaches in the study area, but the foreshore was recovered by gravel nourishment.

Figure 2 shows the coastal condition at the tide level of $0.7 \mathrm{~m}$ above mean sea level (MSL) on September 8, 2002 before the nourishment. No foreshore existed and severe wave overtopping had occurred along the seawall. Figure 3 shows the coastal condition of the same area at the tide level of $0.6 \mathrm{~m}$ above MSL on November 23, 2006 after the beach nourishment. A wide beach had been recovered and the ground elevation in front of the seawall had increased, exhibiting the effectiveness of gravel nourishment.

\footnotetext{
${ }^{1}$ Public Works Research Center, 1-6-4 Taito, Taito, Tokyo 110-0016, Japan

${ }^{2}$ Takahagi Public Works Office, Ibaraki Prefectural Government, 1405-2 Shimotezuna, Takahagi, Ibaraki 318-0003, Japan
} 


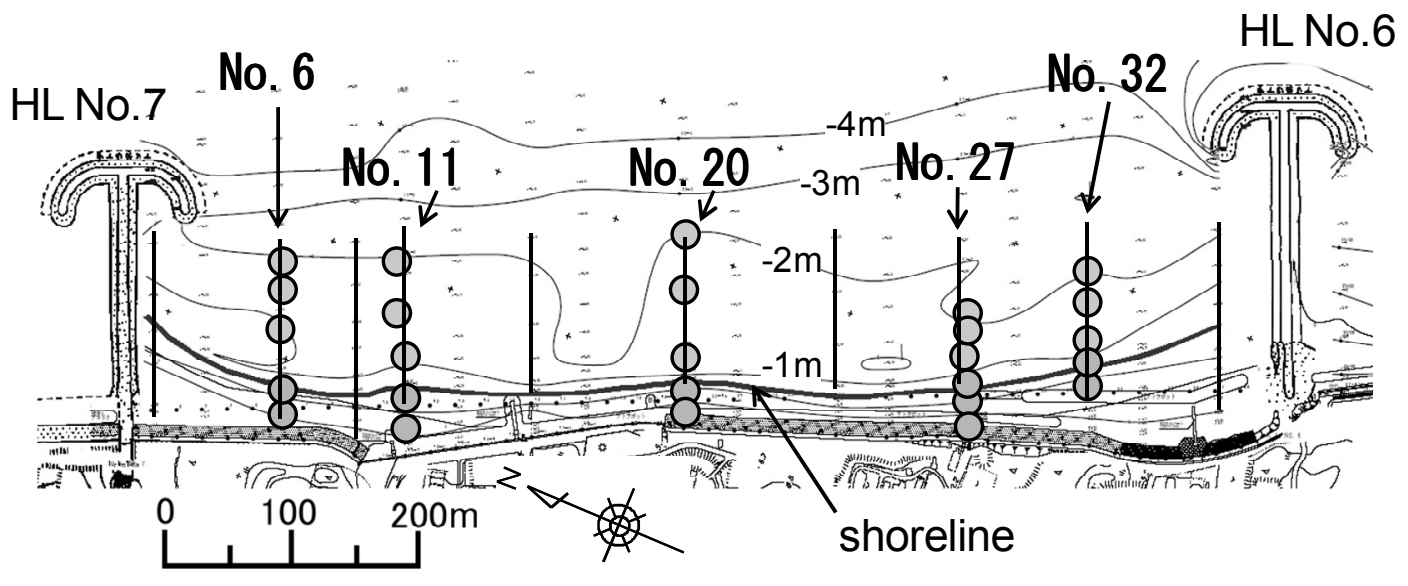

Figure 1. Alignment of transects in study area between artificial headland Nos. 6 and 7 on Jinkoji coast.

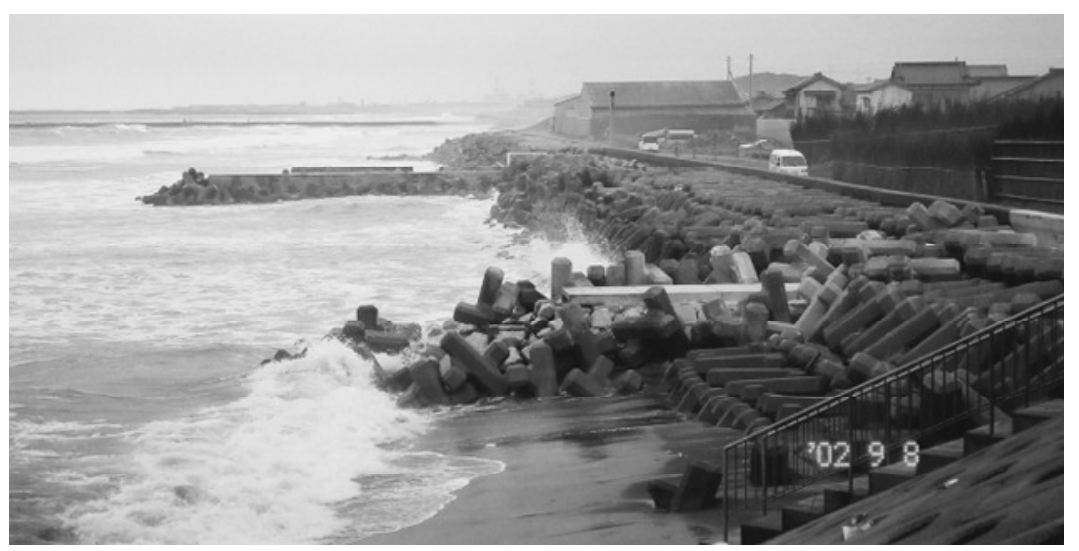

Figure 2. Photograph of Jinkoji coast taken at 17:00 on September 8, 2002 at tide level of $0.7 \mathrm{~m}$ above MSL before gravel nourishment.

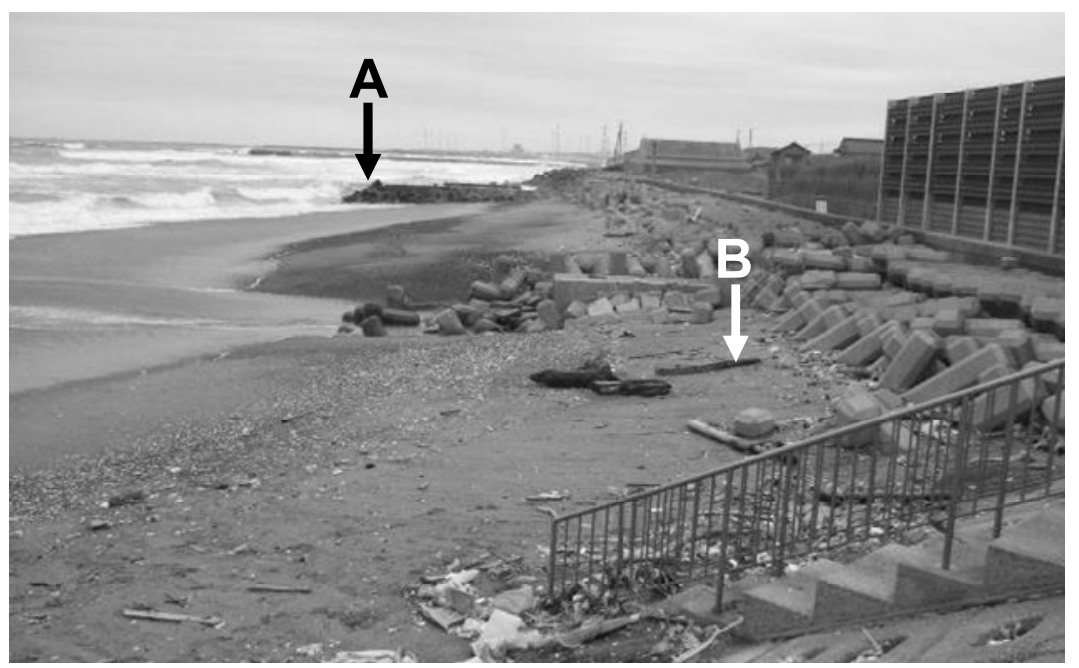

Figure 3. Photograph of Jinkoji coast taken at 16:00 on November 23, 2006 at tide level of $0.6 \mathrm{~m}$ above MSL after gravel nourishment. 
Figure 4 shows the temporal change in the beach volume above MSL and its variation relative to the initial beach topography on November 26, 2005. The volume of the foreshore increased with the beach nourishment, and the net increase in beach volume above MSL was $45,237 \mathrm{~m}^{3}, 52 \%$ of the total nourishment volume of $87,000 \mathrm{~m}^{3}$. Similarly, Fig. 5 shows the temporal change in foreshore area and its variation relative to the initial value on November 26, 2005. The foreshore area increased with the nourishment over time with short-term variations. The variation was large at the initial stage of the nourishment and decreased with time during additional nourishment. The key factor in the variation of the foreshore area is considered to be the seasonal beach changes associated with the change in wave energy.

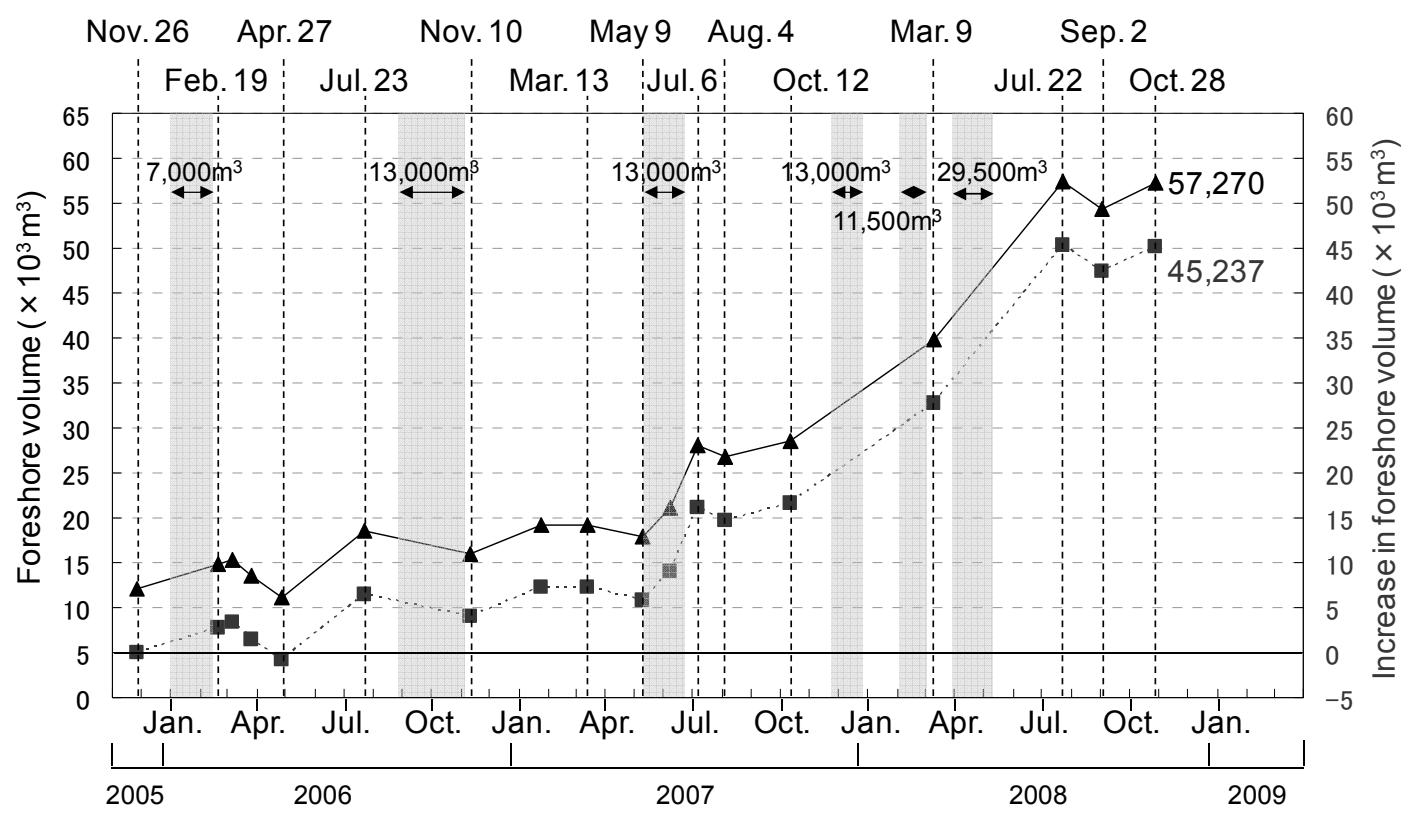

Figure 4. Temporal change in beach volume above MSL and its variation relative to initial beach topography on November 26, 2005.

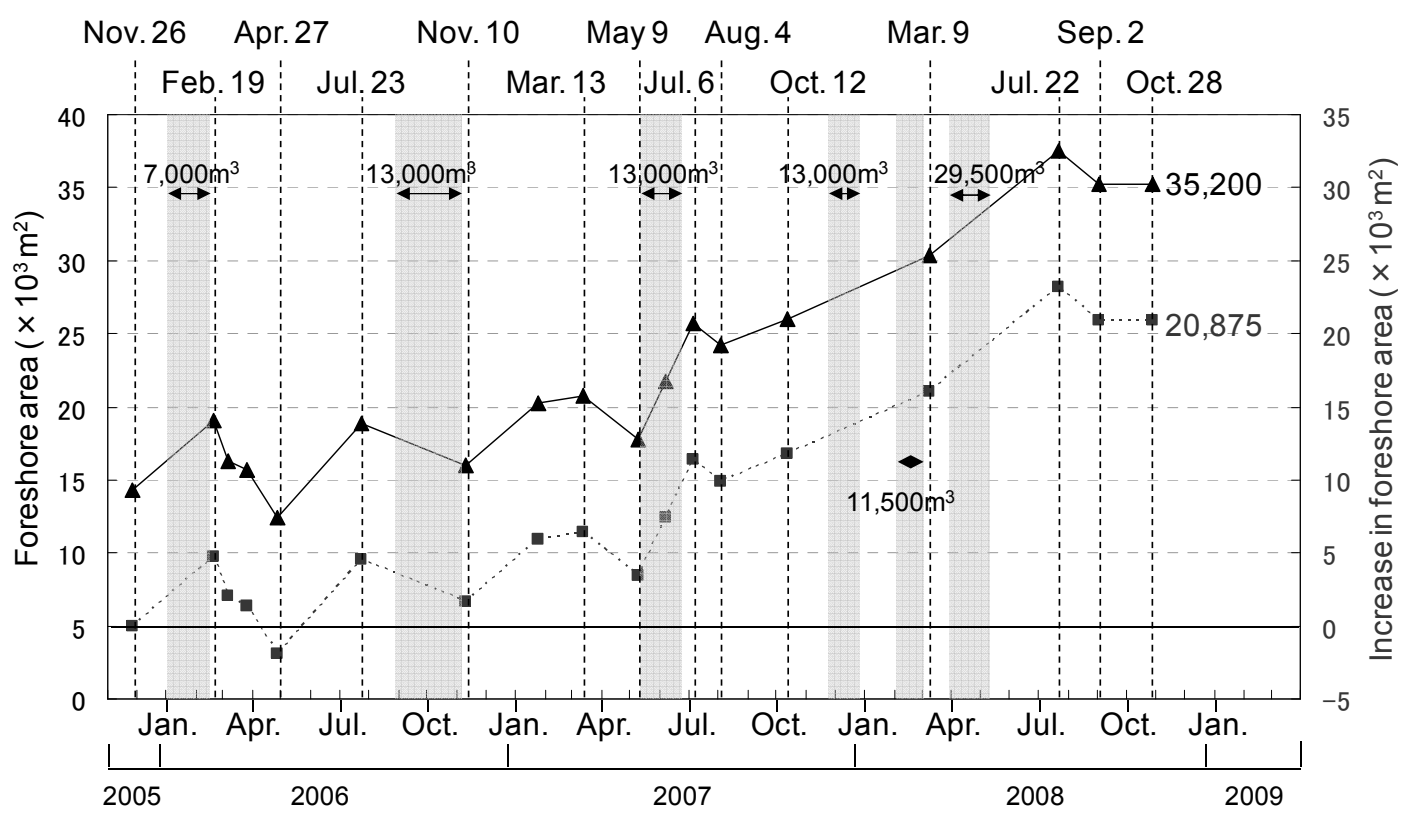

Figure 5. Temporal change in foreshore area and its variation relative to initial value on November 26, 2005. 


\section{(2) Response to waves}

Figure 6 shows the changes in the significant wave height $H_{1 / 3}$ and wave period $T_{1 / 3}$ measured offshore of Kashima Port, $3 \mathrm{~km}$ south of the study site, since November 2005. Comparing the change in $H_{1 / 3}$ with the change in the foreshore area, as shown in Fig. 5, a calm wave condition, during which $H_{1 / 3}$ was smaller than approximately $2 \mathrm{~m}$ continued for a long time during the accretion period, whereas rough wave condition, during which $H_{1 / 3}$ exceeded $2 \mathrm{~m}$, continued during the erosion period. In other words, cross-shore sand transport took place depending on the wave height, and the variation of foreshore area was generated by the cross-shore sand transport. Furthermore, the significant wave height during three periods when the foreshore area rapidly decreased was compared: period I between February 19, 2006 and April 27, 2006; period II between July 23, 2006 and November 10, 2006; and period III between March 13, 2007 and May 9, 2007. The number of occurrences of high waves was zero in period I, four in period II and two in period III, and the decrease in foreshore area was smallest in period III even though the energy level of waves was greatest. Because the net foreshore area increased over time as a result of beach nourishment, it is considered that beach changes were large at the initial stage but gradually decreased with beach nourishment.

Although fine sand was deposited on the foreshore before the gravel nourishment, such sand was transported offshore under the rough wave condition. When fine sand was transported offshore, the beach was filled with gravel. Then fine sand was again transported shoreward under the calm wave condition, but a small amount of fine sand may have been deposited over the gravel layer because of the existence of gravel layer. The thick gravel layer was difficult to transform into a fine sand layer. Thus, it is considered that the gravel content in the layer gradually increased over time.

\section{a: accretion e: erosion}
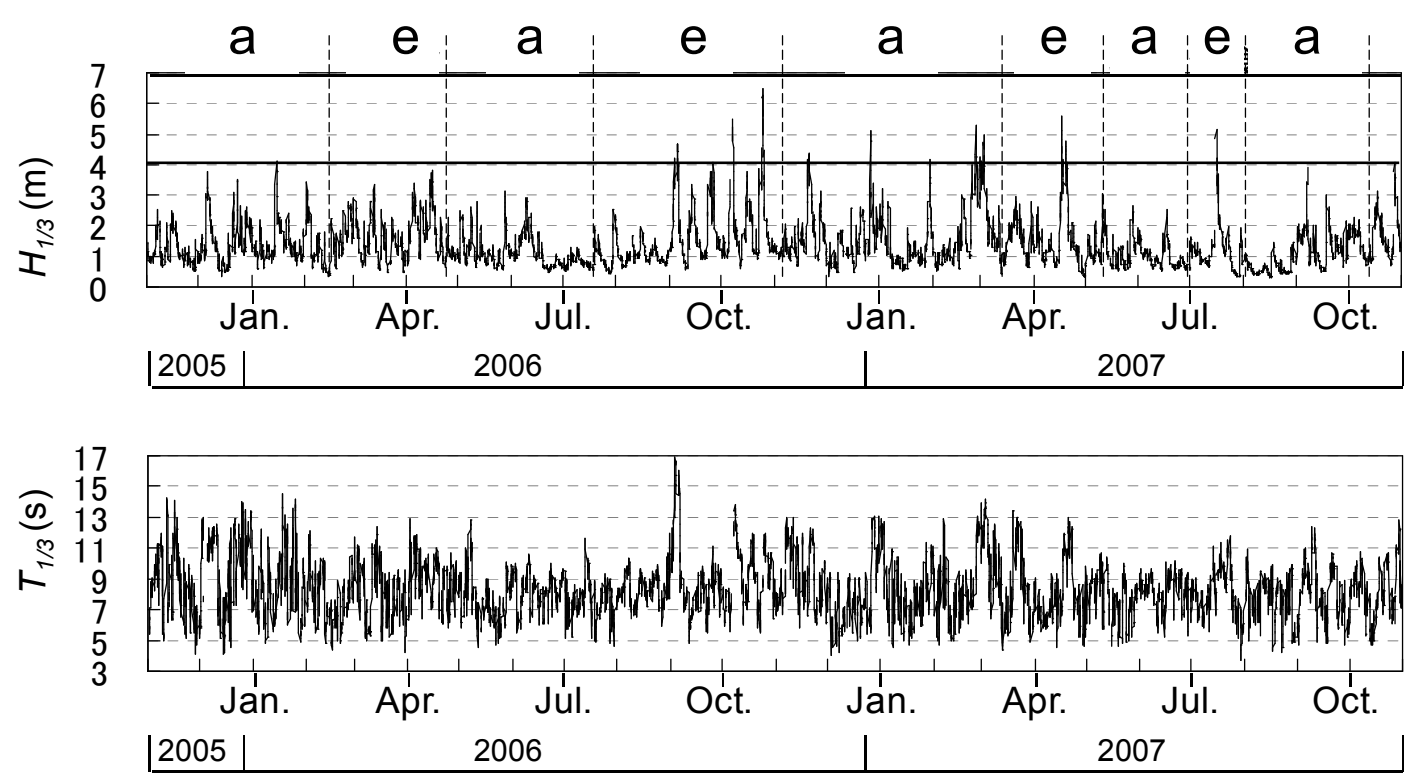

Figure 6. Changes in wave height and wave period during beach nourishment using gravel.

\section{(3) Increases in foreshore area and volume relative to nourishment volume}

To investigate the increase in foreshore area relative to the volume of nourishment gravel, the relationship between the nourishment volume $V_{0}$ and the increase in foreshore area $\triangle A$ was investigated. Equation (1) is satisfied between the two variables with a regression coefficient of $r^{2}=0.92$.

$$
\Delta A=0.26 V_{0}
$$

Taking into consideration the fact that when $\Delta A$ is multiplied by the thickness of the gravel layer, it becomes the change in the volume of gravel, Eq. (1) can be transformed into the approximate relationship $V_{0}=4 \Delta A$. Thus, the total volume of gravel used for nourishment divided by the thickness 
of $4 \mathrm{~m}$ is equal to the increase in foreshore area. Similarly, the relationship between the volume of nourishment gravel $\left(V_{0}\right)$ and the increase in foreshore volume $(\Delta V)$ is investigated. Equation (2) is satisfied between the two variables with a regression coefficient of $r^{2}=0.96$.

$$
\Delta V=0.48 V_{0}
$$

The increase in foreshore volume was $48 \%$ of the total volume of nourishment gravel, implying that approximately half of the nourishment gravel was deposited between MSL and $+2 \mathrm{~m}$ and the remainder was deposited between MSL and $-2 \mathrm{~m}$ to give a total thickness of $4 \mathrm{~m}$.

\section{METHOD OF SHORT-TERM FIELD EXPERIMENTS}

After the completion of gravel nourishment, beach surveys, a drilling test and sampling using core pipes were carried out on July 30 and August 26, 2008 as well as a boring test between July 28 and August 1, 2008. Beach surveys were carried out between $2 \mathrm{~m}$ above and $2 \mathrm{~m}$ below MSL. The drilling test was carried out along 10 transects at elevations with intervals of $1 \mathrm{~m}$, as shown in Fig. 1. The foreshore was manually excavated up to a depth of $0.5 \mathrm{~m}$ from an elevation higher than $1 \mathrm{~m}$ above MSL; below MSL seabed samples were taken up to a depth of $10 \mathrm{~cm}$ beneath the seabed using core pipes. Samples were separated into layers of mud, sand, gravel, and a mixture of sand and gravel, and the thickness of each layer was measured. A boring test, in which a core with a diameter of $\phi=66 \mathrm{~mm}$ was taken, was carried out at locations along five transects at elevations of 1.0, 0.5, -1.0, -1.5 and -2.0 $\mathrm{m}$, as shown by circles in Fig. 1. The depth of core boring was sufficient to reach the original sand layer.

To investigate the cross-shore and longshore changes in the grain size of sand deposited on the foreshore, foreshore material was also sampled at locations along ten transects between transects No. 1 and No. 37 at elevations of 2.0, 1.0 and 0.0 m above MSL on July 30, 2008, as shown in Fig. 1. Wave characteristics during the observation period were measured by a pressure-type wave gauge installed at a depth of $10 \mathrm{~m}$ offshore of the study site.

\section{RESULTS OF BORING TEST}

Figures 7 to 10 show the vertical distribution of sand layers measured by the boring test on July 30 , 2008 along transect Nos. 6, 20, 27 and 32 along with the longitudinal profiles in November 2005 before the nourishment. On the shore face along transect No. 6, the ground elevation increased by a maximum of $3 \mathrm{~m}$ owing to the gravel nourishment while alternate layers composed of sand, gravel, and a mixture of sand and gravel were formed, whereas in the offshore bed only fine sand was deposited without the formation of a gravel layer (Fig. 7). On the shore face along transect No. 20, located midway between headland Nos. 6 and 7 where the foreshore was narrowest, alternate layers were formed on the foreshore, and no gravel was observed on the seabed (Fig. 8). Although the seabed elevation decreased in the offshore zone compared with that before the nourishment, this decrease in seabed elevation is considered to be caused by the movement of fine sand, which had previously covered the offshore bed.

Along transect No. 27, near headland No. 7, a triangular foreshore was formed and a thick mud layer was observed as one of the lower layers at the measuring point of elevation $2 \mathrm{~m}$ along this transect (Fig. 9) because of the deposition of mud transported by a drainage channel from the hinterland. Although the offshore seabed was also eroded along this transect, fine sand was deposited on the sea bottom. Along transect No. 32, close to headland No. 6, gravel was deposited on the shore face with a steep slope between the elevations $-1 \mathrm{~m}$ and $2.5 \mathrm{~m}$ (Fig. 10).

Considering the original seabed with a gentle slope of $1 / 45$ through an imaginary shoreline at the foot of the seawall in the longitudinal profile on November 26, 2005 before the nourishment, nourishment gravel was deposited with a foreshore slope of $1 / 8$ on this gentle slope. Thus, gravel was deposited forming a foreshore backed by the seawall without offshore movement, suggesting that gravel nourishment has high efficiency for the protection of the foot of the seawall. 


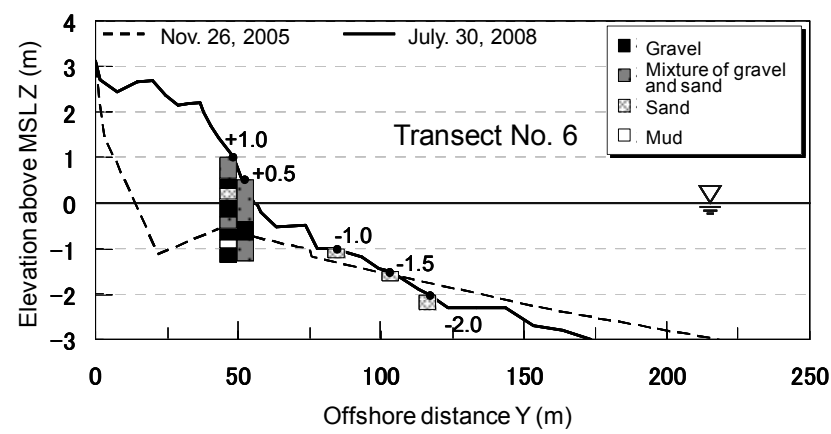

Figure 7. Vertical distribution of sand layers along transect No. 6.

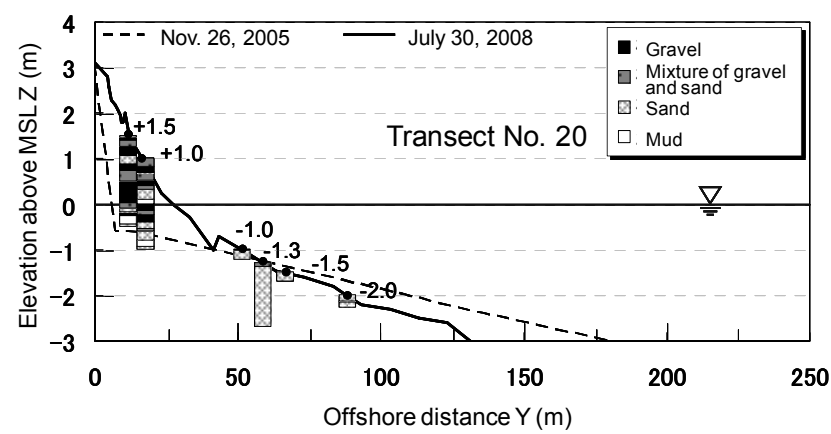

Figure 8. Vertical distribution of sand layers along transect No. 20.

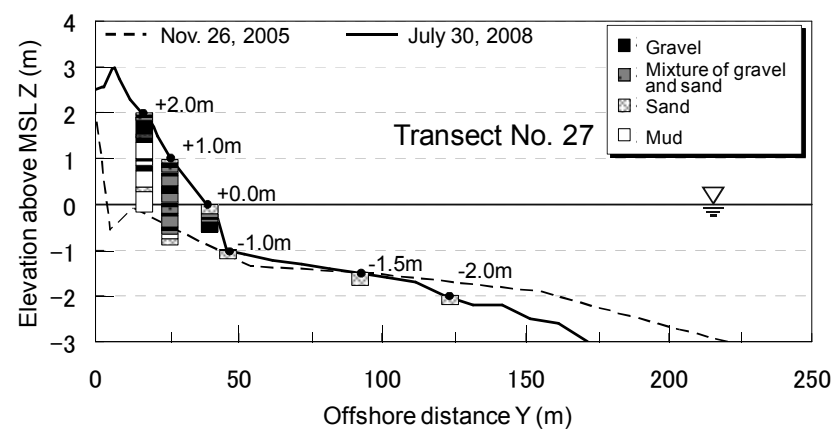

Figure 9. Vertical distribution of sand layers along transect No. 27.

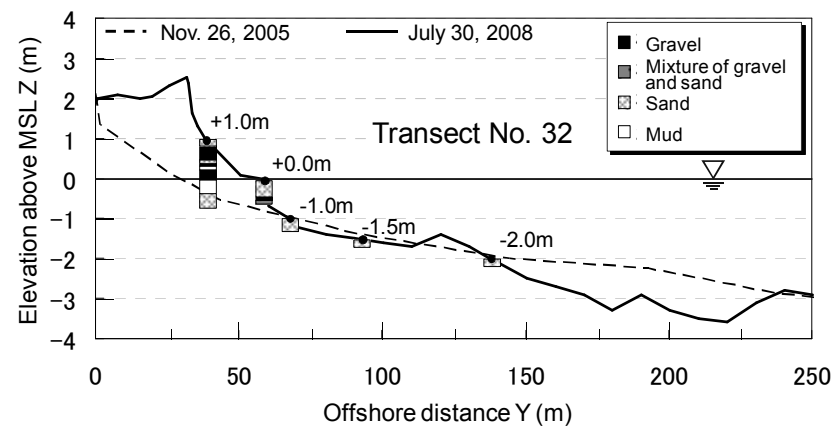

Figure 10. Vertical distribution of sand layers along transect No. 32. 


\section{RESULTS OF DRILLING TEST AND SAMPLING USING CORE PIPES}

Figure 11 shows the changes in $H_{1 / 3}$ and $T_{1 / 3}$ between July 29 and September 2, 2008 during the short-period field observation. Although a calm wave condition continued in general during the observation period, storm waves with $H_{1 / 3}=2.2 \mathrm{~m}\left(T_{1 / 3}=8.6 \mathrm{~s}\right)$ were also occasionally incident to the study site.

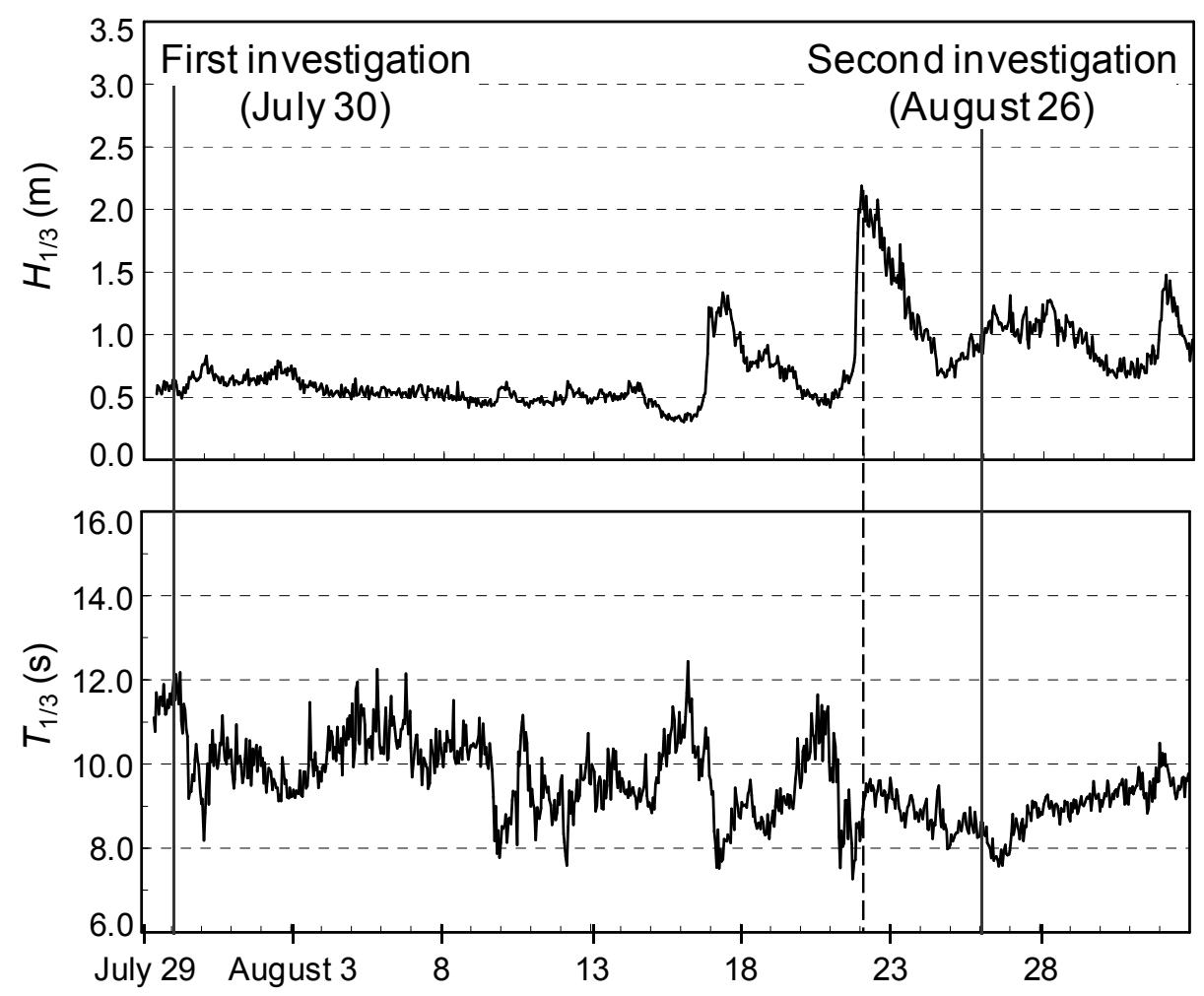

Figure 11. Changes in $H_{1 / 3}$ and $T_{1 / 3}$ during short-term field observation between July 29 and September 2, 2008.

Figure 12(a) shows the longitudinal profile along transect No. 6 and the locations of the drilling test on July 30 and August 26. Points A, B, C, D and E correspond to the locations with elevations of 2.0, 1.0, 0.0, -1.0 and $-2.0 \mathrm{~m}$ above MSL in the longitudinal profile taken on July 30, and a drilling test was carried out at each point. Figure 12(b) shows the change in ground elevation between July 30 and August 26. The foreshore was eroded by storm waves with $H_{1 / 3}=2.2 \mathrm{~m}$ on August 21, resulting in a decrease in ground elevation of up to $1 \mathrm{~m}$, and the elevation at each point became $+1.4 \mathrm{~m} \mathrm{(A),}+0.1 \mathrm{~m}$ (B), $-1.0 \mathrm{~m}(\mathrm{C}),-0.9 \mathrm{~m}$ (D) and $-2.0 \mathrm{~m}(\mathrm{E})$. The vertical distributions of sand layers measured on July 30 and August 26 are shown in Figs. 12(c) and 12(d), respectively. The content of gravel was high at point $\mathrm{A}$ in both observations, but the surface at point B near the shoreline was covered with fine sand. Although the ground elevation at point B decreased by $0.9 \mathrm{~m}$ from $+1.0 \mathrm{~m}$ to $0.1 \mathrm{~m}$ between July 30 and August 26, the content of fine sand remained high. At point $\mathrm{C}$, located on the shoreline on July 30 and at $-1.0 \mathrm{~m}$ on August 26, the content of gravel was high in both observations. At point D, with the initial ground elevation of $-1 \mathrm{~m}$, where a small amount of fine sand was deposited owing to offshore sand transport, the deposition of fine sand was predominant. 


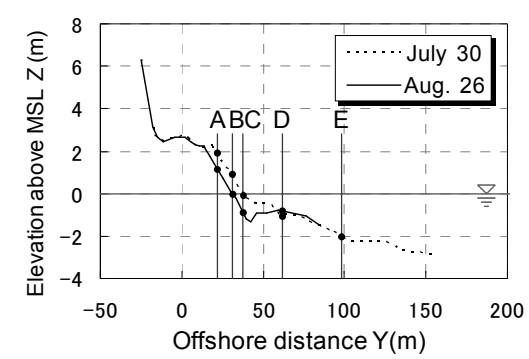

(a) Location of sampling points (Transect No. 6)

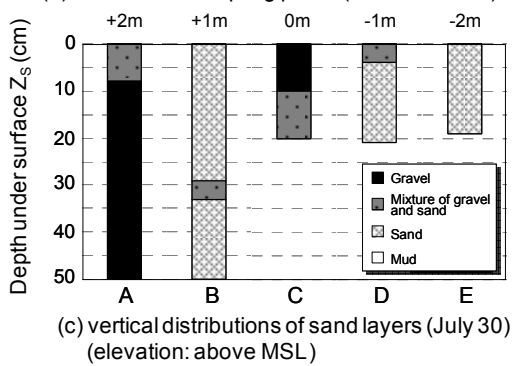

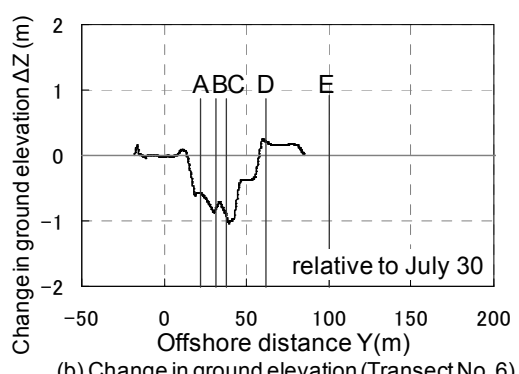

(b) Change in ground elevation (Transect No. 6)

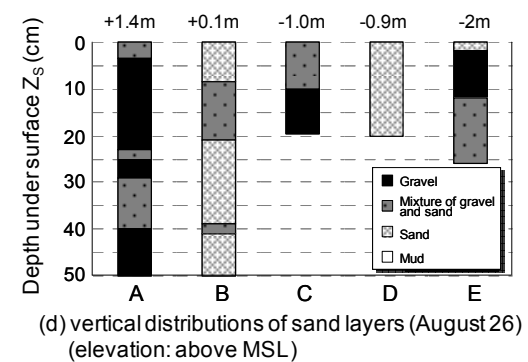

Figure 12. Changes in longitudinal profile and sand layer along transect No. 6.

Figure 13 shows the results along transect No. 20 located midway between headland Nos. 6 and 7 . The foreshore width was narrow at this transect because of the protrusion of the seawall. During the observation period, the depth of the seabed immediately offshore of the shoreline increased to $-2.1 \mathrm{~m}$ between points $\mathrm{C}$ and $\mathrm{D}$, and the depth of scoring reached a maximum of $1.5 \mathrm{~m}$. Along this transect the foreshore surface was covered with coarser material with decreasing elevation. This is because gravel deposited in the base layer was exposed to the surface due to erosion. However, even though the ground elevation at point D in the offshore zone was decreased, the seabed surface remained covered with fine sand, suggesting that gravel was not deposited near point D and that the probability of the offshore discharge of gravel is extremely small.

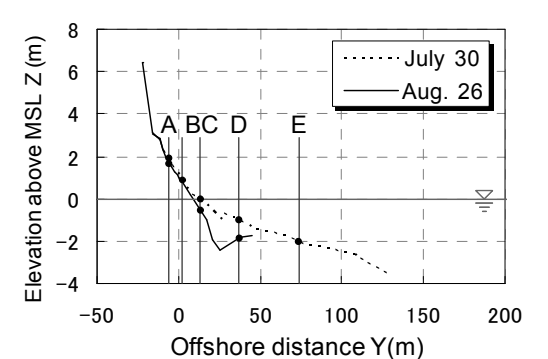

(a) Location of sampling points (Transect No. 20)

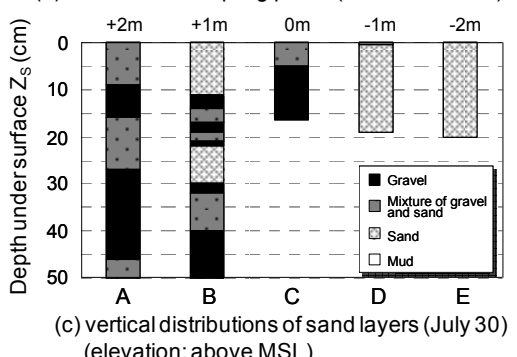

(elevation: above MSL)

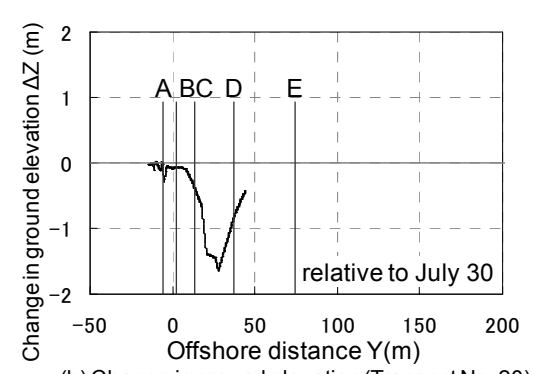

(b) Change in ground elevation (Transect No. 20)

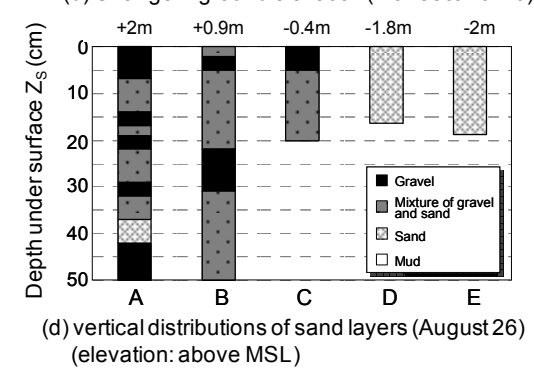

Figure 13. Changes in longitudinal profile and sand layer along transect No. 20. 
Figure 14 shows the results along transect No. 27. During the observation period, the ground elevation of points A and B was approximately constant, but the depth of the seabed between points $\mathrm{C}$ and $\mathrm{D}$ increased with a maximum depth of scoring of $1.2 \mathrm{~m}$. The change in the longitudinal profile is similar to that along transect No. 20, as shown in Fig. 13. Along this transect, no large changes were observed in the alternate layers composed of gravel, and sand and gravel at points A and B, whereas coarser material was deposited at the surface layer of point $\mathrm{C}$ after erosion. Nevertheless, the offshore seabed at points D and E remained covered with fine sand.

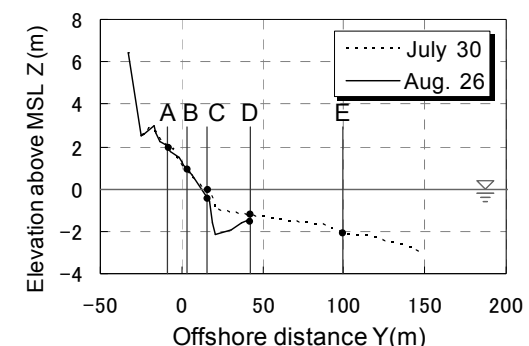

(a) Location of sampling points (Transect No. 27)

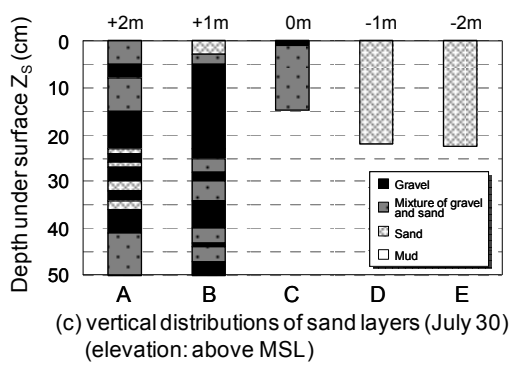

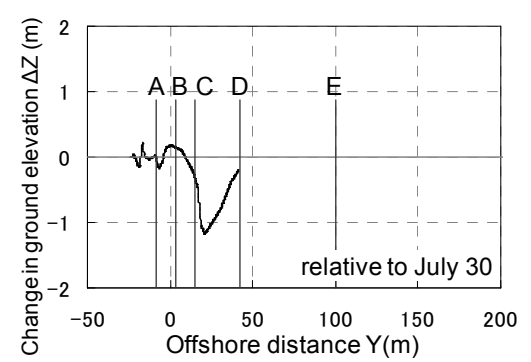

(b) Change in ground elevation (Transect No. 27)

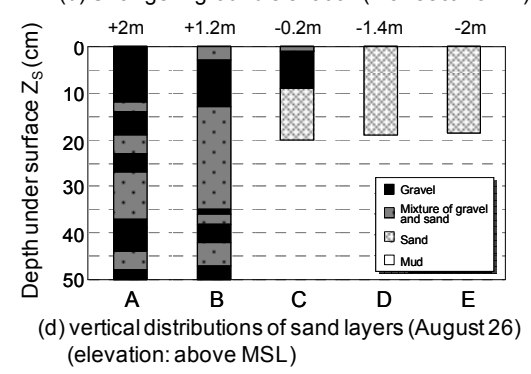

Figure 14. Changes in longitudinal profile and sand layer along transect No. 27.

Figure 15 shows the results along transect No. 32. Along this transect, a berm with a crown height of $2.6 \mathrm{~m}$ was formed after the action of storm waves, in contrast to the erosion along other transects. The increase in ground elevation between points A and B was $0.5 \mathrm{~m}$. With the accretion, coarser material was deposited at points $\mathrm{A}, \mathrm{B}$ and $\mathrm{C}$ on the foreshore, whereas the seabed surface was covered with fine sand at points $\mathrm{D}$ and $\mathrm{E}$ in the offshore zone.

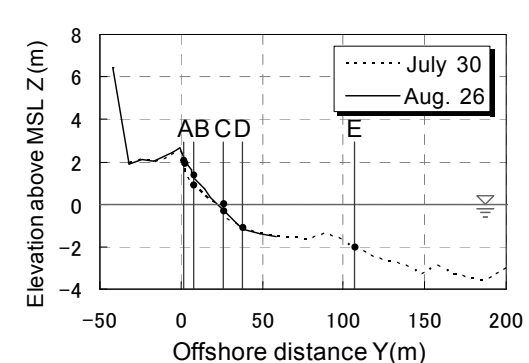

(a) Location of sampling points (Transect No. 32)

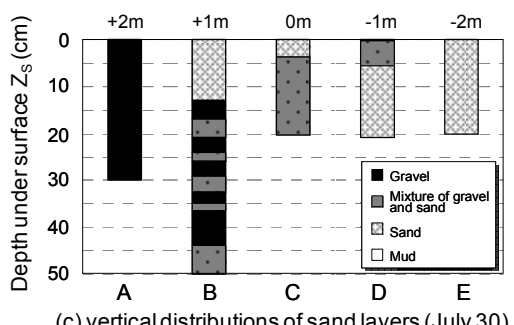

(c) vertical distributions of sand layers (July 30 ) (elevation: above MSL)

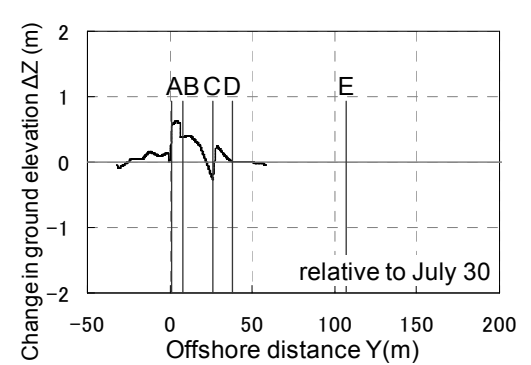

(b) Change in ground elevation (Transect No. 32)

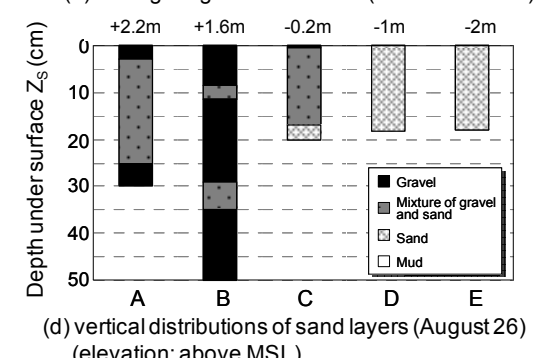

(elevation: above MSL)

Figure 15. Changes in longitudinal profile and sand layer along transect No. 32. 
The cross-shore distribution of the ratio of the thickness of the gravel layers to the total thickness of the core sample, defined as the sum of the thickness of each gravel layer divided by the total thickness, as shown in Fig. 16, was determined using dataset measured by three methods. Figure 17 shows the cross-shore distribution of the ratio of the thickness of the gravel layers along transect No. 6. A steep foreshore slope of $1 / 8$ and a gentle slope of $1 / 50$ in the offshore zone intersect at a depth of $0.5 \mathrm{~m}$, and the ratio suddenly decreases at this point. In other words, the thickness of the gravel layer relative to the total thickness of the core sample is large in the zone landward of the depth of $0.5 \mathrm{~m}$, whereas offshore of this point the content of the gravel layer is 0 .

Figure 18 shows the depth distribution of the thickness of the gravel layers as a proportion of the total core thickness measured on July 30 and August 26, 2008 using three methods. The proportion of gravel is only high above MSL, and it is 0 in the zone deeper than $-0.5 \mathrm{~m}$, even though the wave conditions on July 30 and August 26, 2008 differ from each other.

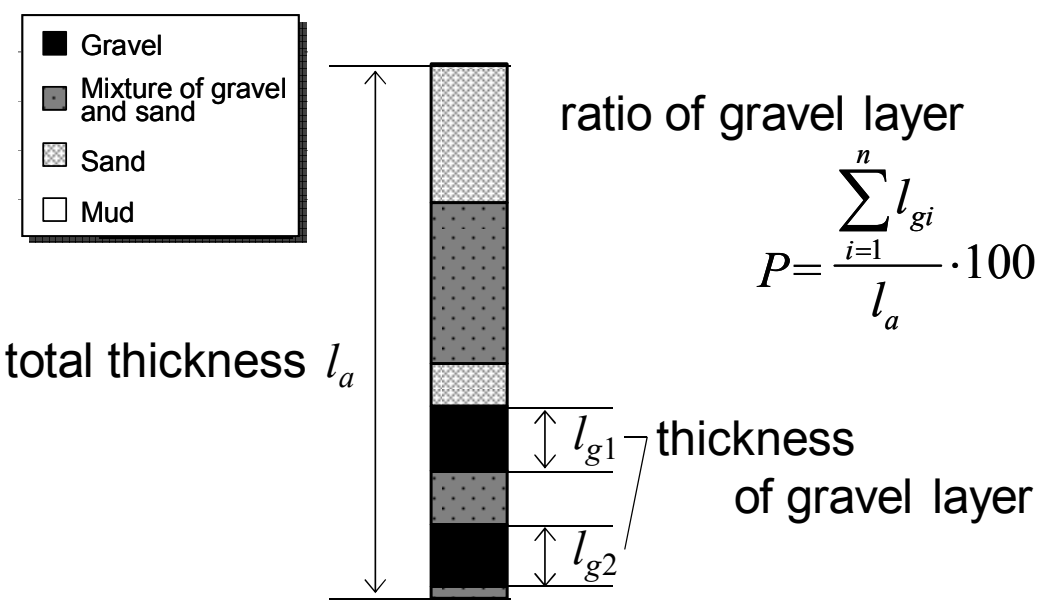

Figure 16. Definition of ratio of thickness of gravel layers.

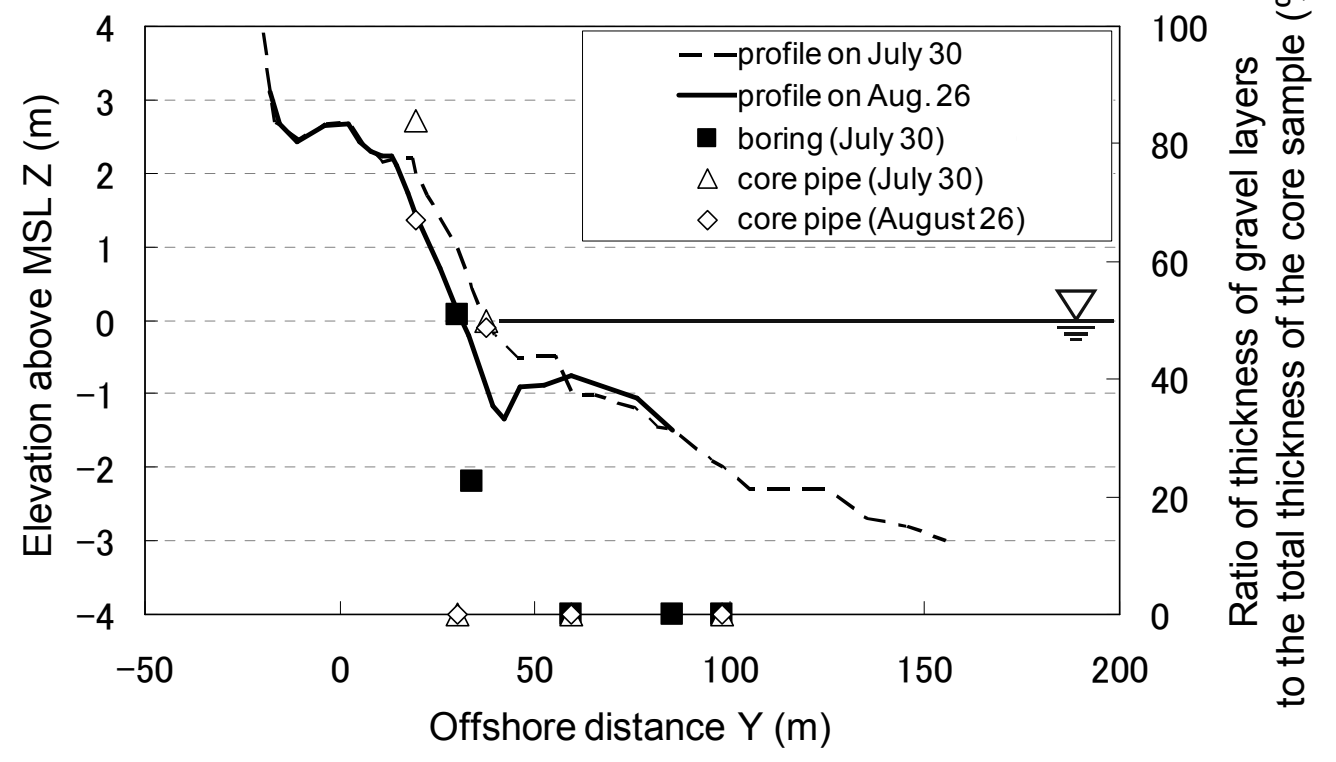

Figure 17. Cross-shore distribution of ratio of thickness of gravel layers along transect No. 6. 


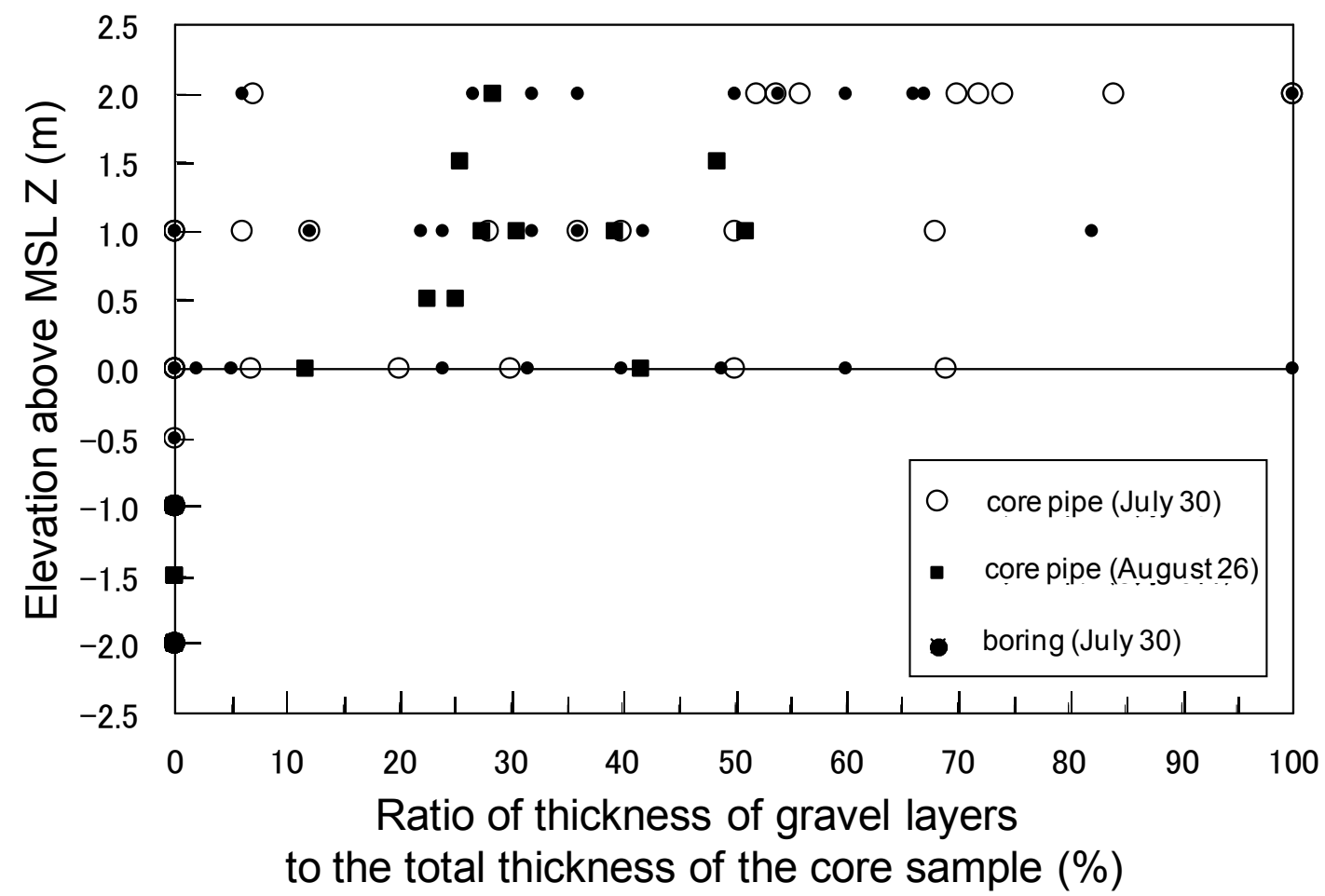

Figure 18. Depth distribution of ratio of thickness of gravel layers.

\section{CHANGE IN GRAIN SIZE OF SAND DEPOSITED ON FORESHORE}

Figures 19 and 20 respectively show the changes in the grain size of sand deposited at elevations of 2 and $1 \mathrm{~m}$ above MSL on the foreshore. During the observation, the foreshore was eroded owing to storm waves with $H_{1 / 3}=2.2 \mathrm{~m}$ on August 21, and the average ground elevations of 2.0 and $1.0 \mathrm{~m}$ measured on July 30 had been reduced to 1.9 and $0.8 \mathrm{~m}$, respectively, by August 26 .

At the point with the elevation of $2.0 \mathrm{~m}$ on July 30, only gravel was deposited at both ends of the pocket beach and the contents of fine and coarse sand were large in the central part of the pocket beach (Fig. 19). On August 26 after the storm waves, however, the content of gravel markedly increased owing to foreshore erosion. A similar distribution of the content of gravel at the point with the elevation of $1.0 \mathrm{~m}$ on July 30 is shown in Fig. 20. At this elevation, the content of fine sand was as high as $40 \%$ on July 30 due to the shoreward sand transport during the calm condition in summer, but the content of fine sand markedly decreased by up to $20 \%$ and gravel was exposed on August 26 after the storm waves. These characteristics show that even though the gravel layer at the shore face is covered with fine sand, such fine sand is quickly transported offshore during stormy conditions, resulting in the exposure of the gravel layer. 


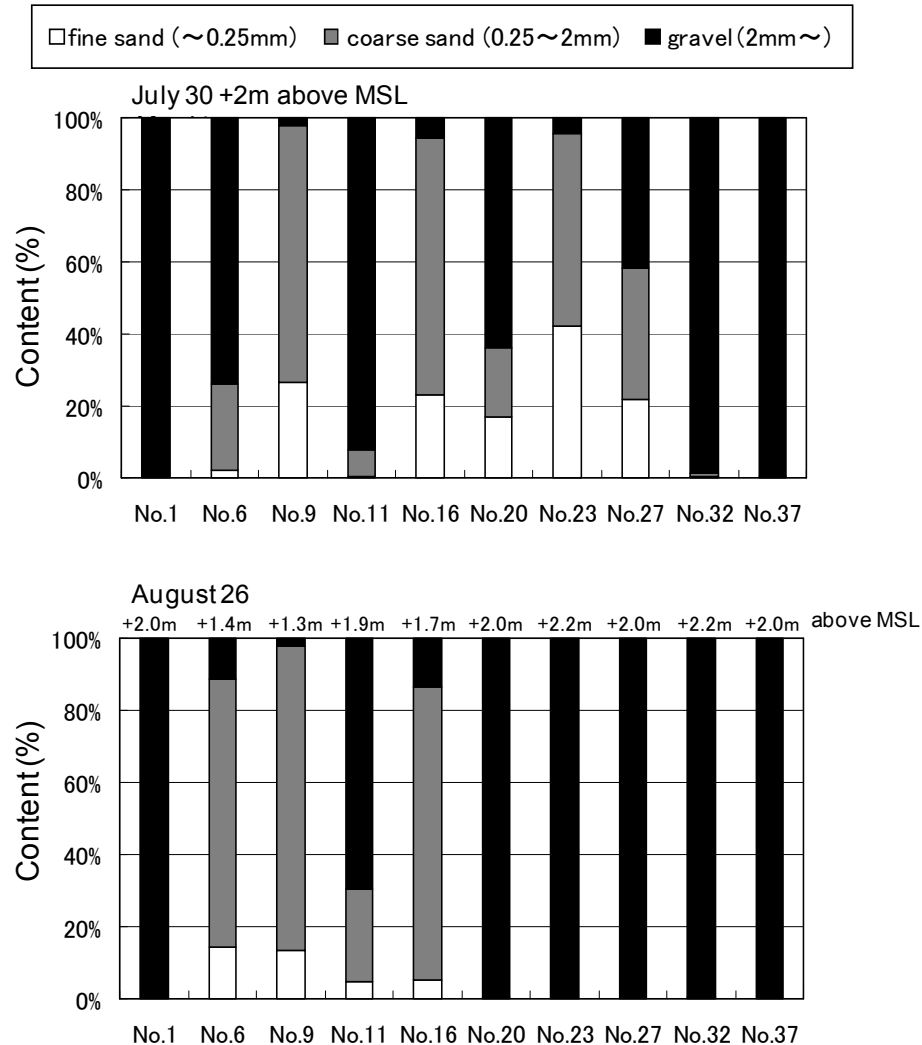

Figure 19. Grain size composition at $2 \mathrm{~m}$ above MSL on shore face on July 30 and August 26, 2008.

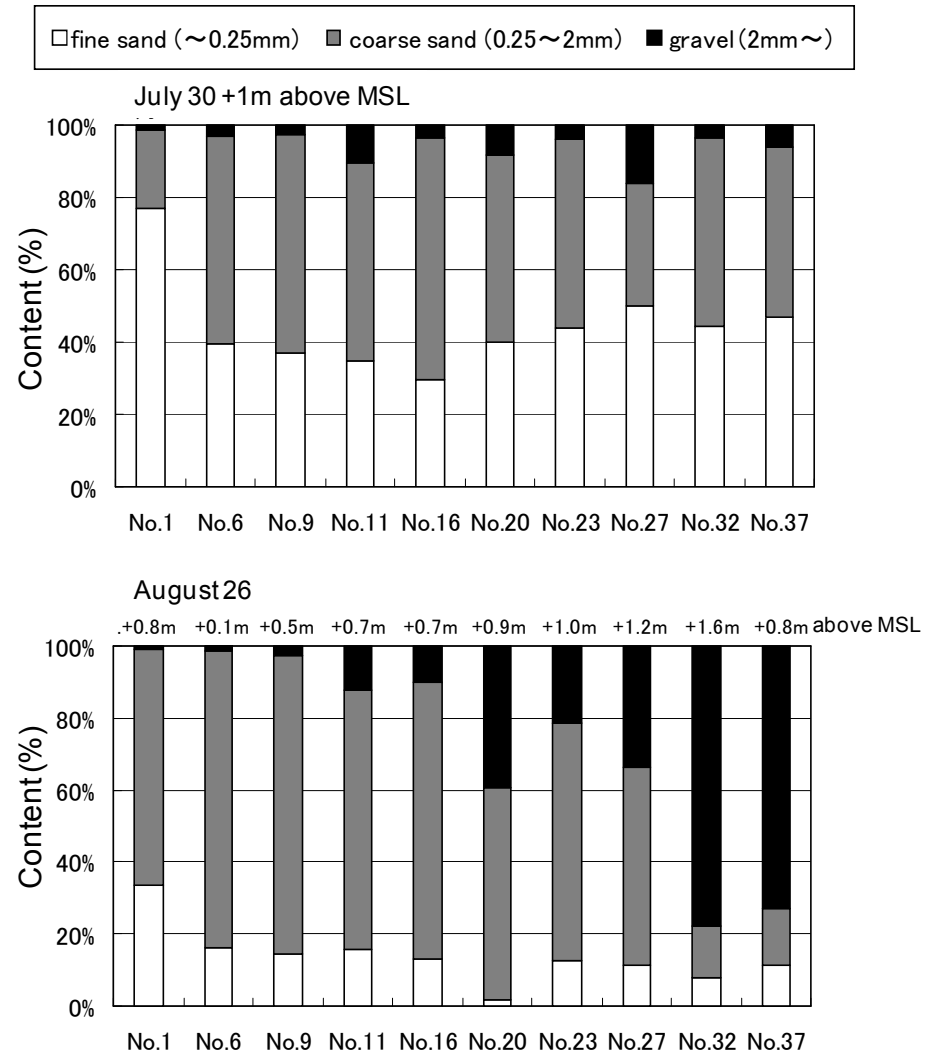

Figure 20. Grain size composition at $1 \mathrm{~m}$ above MSL on shore face on July 30 and August 26, 2008. 


\section{CONCLUSIONS}

1. Beach nourishment using $87,000 \mathrm{~m}^{3}$ of gravel with a grain size ranging between 2.5 and $13 \mathrm{~mm}$ was carried out until April 2008 between headland Nos. 6 and 7 on the Jinkoji coast facing the Pacific Ocean.

2. Nourishment gravel was found to accumulate near the shoreline and remained between the headlands. The gravel was effective in widening the foreshore.

3. Nourishment gravel was deposited on a gentle slope of 1/50 composed of fine sand before nourishment, forming a steep slope of $1 / 8$. Offshore movement of the nourishment gravel was negligible.

4. Nourishment using gravel was effective for protecting the foot of the seawall by raising the beach elevation and reducing wave overtopping.

5. The total thickness of deposited gravel was $4 \mathrm{~m}$, half of which was deposited above MSL to a height of $2 \mathrm{~m}$ and the remainder was deposited below MSL to a depth of $2 \mathrm{~m}$.

\section{REFERENCES}

Komar, P. D. 2007. The design of stable and aesthetic beach fills: Learning from Nature, Coastal Sediments 07, 420-433.

Kumada, T., T. Uda, M. Serizawa, H. Ishii, T. Nakamura and Y. Oki. 2007. Numerical simulation and field experiment on beach nourishment using coarse materials, Asian and Pacific Coasts 2007, Proc. $4^{\text {th }}$ Inter. Conf., 1094-1105.

Matsu-ura, T., T. Uda, T. Kumada and H. Nagayama. 2008. Evaluation of stabilization effect by artificial headlands built on Kashimanada coast using model for predicting changes in contour lines and grain sizes, Proc. $31^{\text {st }}$ ICCE, 1888-1900. 